\title{
The Impact of Biological, Ecological and Technologi- cal Factors on the Forage Yield of Complex Mixtures of Perennial Grasses and Legumes
}

\author{
Nicuşor SIMA ${ }^{1}$, Doru CRISTE ${ }^{1}$ and Rodica SIMA² ${ }^{*}$ \\ ${ }^{1}$ Faculty of Animal Husbandry and Biotechnology, University of Agriculture Science and Veterinary \\ Medicine Cluj-Napoca, Romania \\ ${ }^{2}$ Faculty of Horticulture, University of Agriculture Science and Veterinary Medicine Cluj-Napoca, Roma- \\ nia \\ ${ }^{*}$ Corresponding author, e-mail: rodiganea@.yahoo.com
}

Bulletin USAMV series Agriculture 71(2)/2014

Print ISSN 1843-5246; Electronic ISSN 1843-5386

DOI 10.15835/buasvmcn-agr: 10650

\begin{abstract}
The negative impact of climatic changes is obviously in the forage production. Therefore the knowledge of biological characteristics, requirements and reactions at environmental conditions of different fodder species which compose complex mixtures becomes very important. The objective of the experiment was to establish some mixtures of perennial grasses and legumes, respectively some technological variants of fertilization which can provide certain fodder harvests. The mixtures which revealed very significant yield increases in comparison with pure alfalfa crop, considered as control, regardless the level of fertilization and the experimental year, were M7, M8 (new mixtures) and M5 (mixture already on market).
\end{abstract}

Keywords: climate change, temporary pastures, cutting

\section{INTRODUCTION}

The negative impact of climatic changes through extreme weather phenomena such as drought, floods and hails affected in the last year the Romanian farmers. The most vulnerable at these extreme conditions are the annual crops regardless their destination, such as human consumption or fodder. Thus, animal breeders have to adopt a malleable strategy in the fodder production which has to include both annual and perennial crops with different species and cultivars adapted to the new climatic conditions. Temporary pastures with complex mixtures of perennial grasses and legumes are less vulnerable at less favourable ecological conditions for plant growth and development compared to annual crops and represent real solutions for fodders production (Motcă etal. 1994, Vîntu et al. 2004). The use of hay obtained from temporary pastures in the animal feeding is very important for Romanian farmers. The knowledge of biological characteristics, requirements and reactions of some species, cultivars and mixtures of perennial fodder plants existing on market at different environmental and technological conditions becomes also very important. The shortage of updated information regarding the reaction of perennial grasses and legumes mixtures at the ecological conditions specific to the different Romanian areas imposes researches in this respect.

\section{MATERIALS AND METHODS}

The data presented in this paper are the result of the research work conducted between the years 2010 (Y1) - 2011 (Y2) in the experimental field of Didactical and Experimental Station (DES) Cojocna of UASVM Cluj-Napoca. The objective of the experiment was to establish some mixtures of perennial grasses and legumes, respectively some technological variants of fertilization which can provide certain fodder harvests. The experiment was bifactorial, organized according to split-plot method (species/mixture with 9 graduations and fertilization with 3 graduations) 
within a randomized complete block design with three replications. The first experimental factor (species/mixture - M) included the folowing graduations: M1. Medicago sativa L. - control; M2. Medicago sativa L., Trifolium alexandrinum L., Dactylis glomerata L., Lolium x hybridum Hausskn. (40\% grasses and 60\% legumes); M3. Lotus corniculatus L., Onobrychis viciifolia Scop., Dactylis glomerata L., Festuca pratensis Huds., Bromus inermis Leyss. (53\% grasses and 47\% legumes); M4. Medicago sativa L., Dactylis glomerata L., Festuca arundinacea Schreb., Lolium perenne L. (70\% grasses and 30\% legumes); M5. Trifolium pratense L., Dactylis glomerata L., Festulolium Asch.\&Graebn., Phleum pratense L., Lolium perenne L. (85\% grasses and 15\% legumes); M6. Lotus corniculatus L., Phleum pratense L., Dactylis glomerata L., Festuca arundinacea Schreb., Festuca pratensis Huds. (85\% grasses and 15\% legumes); M7. Trifolium pratense L., Lotus corniculatus L., Trifolium alexandrinum L., Dactylis glomerata L., Festuca pratensis Huds., Lolium x hybridum Hausskn. (70\% grasses and 30\% legumes); M8. Trifolium pratense L., Trifolium repens L., Dactylis glomerata L., Festuca pratensis Huds., Phleum pratense L., Lolium $x$ hybridum Hausskn., Lolium perenne L. (78\% grasses and 22\% legumes); M9. Medicago sativa L., Trifolium repens L., Bromus inermis Leyss., Festuca arundinacea Schreb., Lolium $x$ hybridum Hausskn., (76\% grasses and $24 \%$ legumes). Fertilization, the second factor, had 3 levels (N0P0, N60P70 and N120P70 kg.ha-1). The sowing was done during March in 2010, when soil humidity alowed. During vegetation period of each year three cuttings in the heading phenophase of grasses were done, after first one the above mentioned fertilization doses being applied. The dry matter (DM) yield was determined by drying of fresh matter samples in a drying oven at a $60^{\circ} \mathrm{C}$ for $48 \mathrm{~h}$. The obtained data were statistical analyzed using ANOVA test.

\section{RESULTS AND DISCUSSIONS}

The spring of 2010 offered good conditions regarding temperatures and precipitations for germination, growth and development of sown species.

Comparing the dry matter (DM) yield obtained in both experimental years with their average (Tab. 2) it can be observed that the relative uniform assessment of rainfalls during vegetative period of 2010 determined distinctly

Tab. 1. Average monthly temperature and rainfalls during March-August 2010-2011, Cojocna

\begin{tabular}{ccccc}
\hline $\begin{array}{c}\text { Year/ } \\
\text { Month } \\
2010 / 2011\end{array}$ & $\begin{array}{c}\text { Average } \\
\text { monthly } \\
\text { temperature } \\
\left({ }^{\circ} \mathrm{C}\right)\end{array}$ & $\begin{array}{c}\text { Rainfalls } \\
(\mathrm{mm})\end{array}$ & $\begin{array}{c}\text { Average } \\
\text { monthly } \\
\text { temperature } \\
\left({ }^{\circ} \mathrm{C}\right)\end{array}$ & $\begin{array}{c}\text { Rainfalls } \\
(\mathrm{mm})\end{array}$ \\
\hline March & 6.85 & 9.20 & 4.75 & 0.00 \\
\hline April & 11.30 & 63.40 & 10.23 & 10.40 \\
\hline May & 17.21 & 133.40 & 15.07 & 14.60 \\
\hline June & 21.24 & 197.00 & 19.24 & 18.20 \\
\hline July & 23.10 & 141.40 & 20.25 & 101.00 \\
\hline August & 21.44 & 45.00 & 20.23 & 10.60 \\
\hline
\end{tabular}

Tab. 2. Variation with year in the DM yield $\left(\mathrm{t} \cdot \mathrm{ha}^{-1}\right)$

\begin{tabular}{ccccc}
\hline Year & $\begin{array}{c}\text { DM yield } \\
\left(\mathrm{t} \cdot \mathrm{ha}^{-1}\right)\end{array}$ & $\begin{array}{c}\text { Yield } \\
\%\end{array}$ & $\begin{array}{c}\text { Differences } \\
+/-\left(\mathrm{t} \cdot \mathrm{ha}^{-1}\right)\end{array}$ & Significance \\
\hline Year average & 12.24 & 100 & 0 & Control. \\
\hline 2010 & 13.01 & 106.3 & 0.77 & $* *$ \\
\hline 2011 & 11.47 & 93.7 & -0.77 & 0 \\
\hline \multicolumn{4}{c}{ LSD (p 5\%) $0.51 ;$ LSD (p 1\%) 0.68; LSD (p 0.1\%) 0.89} \\
\hline
\end{tabular}


significant yield increase. The drought conditions in 2011 strongly affected the regrowth cacapacity of species conducting to a significantly decrease of yield. The biological characteristics of species and their ecological requirements determined different reaction of mixtures as yields (Tab. 3).

All tested mixtures revealed higher yields in comparison with pure alfalfa crop, considered as control, in 2010 conditions, the first year of vegetation/production (Tab.3). Among the mixtures with very sinificant yield increases in comparison with pure alfalfa crop can be remarked M7. Trifolium pratense L., Lotus corniculatus L., Trifolium alexandrinum L., Dactylis glomerata L., Festuca pratensis Huds., Lolium $x$ hybridum Hausskn. (70\% grasses and 30\% legumes); M2. Medicago sativa L., Trifolium alexandrinum L., Dactylis glomerata L., Lolium x hybridum Hausskn. (40\% grasses and $60 \%$ legumes); M8. Trifolium pratense L., Trifolium repens L., Dactylis glomerata L., Festuca pratensis Huds., Phleum pratense L., Lolium $x$ hybridum Hausskn., Lolium perenne $L$. (78\% grasses and $22 \%$ legumes) - all of them new mixtures, respectively M5. Trifolium pratense L., Dactylis glomerata L., Festulolium Asch.\&Graebn., Phleum pratense L., Lolium perenne L. (85\% grasses and $15 \%$ legumes) - mixture already on the market. Mixtures M7 and M8 were composed of 7 species while M2 and M5 were composed of 4 , respectively 5 species. The composition of M7, M8 and M5 mixtures at sowing was dominated by grasses while only in mixture M2, legumes had a higher ratio than grasses.

Analysing the influence of fertilization on the DM yield the positive impact of N120P70 kg.ha-1 dose can be observed (Tab. 4). All the variants fertilized with this dose revealed very significant yield increases.

Tab. 3. The combined influence of mixture and year on the DM yield ( $\left.\mathrm{t} \cdot \mathrm{ha}^{-1}\right)$

\begin{tabular}{ccccc}
\hline Mixture x Year & $\begin{array}{c}\text { DM yield } \\
\left(\mathrm{t} \cdot \mathrm{ha}^{-1}\right)\end{array}$ & $\begin{array}{c}\text { Yield } \\
\%\end{array}$ & $\begin{array}{c}\text { Differences } \\
+/-\left(\mathrm{t} \cdot \mathrm{ha}^{-1}\right)\end{array}$ & Significance \\
\hline M1Y1 & 10.42 & 100 & 0 & Control. \\
\hline M2Y1 & 15.19 & 145.8 & 4.77 & $* * *$ \\
\hline M3Y1 & 11.1 & 106.6 & 0.69 & - \\
\hline M4Y1 & 11.22 & 107.7 & 0.8 & - \\
\hline M5Y1 & 13.88 & 133.3 & 3.47 & $* * *$ \\
\hline M6Y1 & 10.43 & 100.1 & 0.01 & - \\
\hline M7Y1 & 17.48 & 167.8 & 7.06 & $* * *$ \\
\hline M8Y1 & 14.94 & 143.4 & 4.52 & $* * *$ \\
\hline M9Y1 & 12.44 & 119.4 & 2.02 & ** \\
\hline LSD (p 5\%) 1.45 & LSD (p 1\%) 1.96 & LSD (p 0.1\%) 2.62 \\
\hline M1Y2 & 9.75 & 100 & 0 & Control. \\
\hline M2Y2 & 9.34 & 95.7 & -0.42 & - \\
\hline M3Y2 & 9.77 & 100.2 & 0.02 & - \\
\hline M4Y2 & 12.43 & 127.4 & 2.68 & $* * *$ \\
\hline M5Y2 & 13.16 & 135 & 3.41 & $*$ \\
\hline M6Y2 & 10.94 & 112.2 & 1.19 & $* * *$ \\
\hline M7Y2 & 13.26 & 135.9 & 3.5 & - \\
\hline M8Y2 & 13.89 & 142.4 & 4.14 & *** \\
\hline M9Y2 & 10.71 & 109.8 & 0.95 & LSD (p 0.1\%) 2.62 \\
\hline LSD (p 5\%) 1.45 & LSD (p 1\%) 1.96 & \\
\hline & & & & $*$ \\
\hline
\end{tabular}


The obtained yields indicated the ability of species within mixtures to use efficiently the existing vegetation factors in accordance with their biological charactyeristics such as the development rate and the competition capacity (Tab. 5). Some examples of fodder plants which are less known by Romanian farmers but which have a rapid rate of development and a high competitiveness are Festulolium braunii and Lolium $x$ hybridum hybrids and Trifolium alexandrinum specie. These new hybrids combine the positive traits of their genitors. Festulolium braunii, the italian type, is a tetraploid of Festulolium derived from the cross between italian ryegrass and meadow fescue (www.dlfis. com). Lolium $x$ hybridum, the hybrid ryegrass, is a tetraploid, respectively a synthetic cultivar derived from the cross between italian ryegrass and perennial ryegrass (Schitea Maria et al., 2002). The characteristics of these species add value to the mixtures in which they are found. An example in this respect is M7 mixture. In this mixture an important role in the competition with weeds can be confer to Trifolium alexandrinum and Trifolium pratense species, thanks to their biological characteristics. Both species have a short life span and a rapid rate of development (Dragomir, 2005; Varga et al., 1998). These characteristics determine, especially with $T$. alexandrinum, a massive development immediately after plant emergence, with an advantage in the competition for light with the other species. This advantage is related to its architecture, which is similar with that of alfalfa (Schitea and Varga, 2007). Agood argumentfor those mentioned is represented by the evolution of DM yield in M2 mixture in 2011 (Tab. 3). Only in this mixture a decrease of yield in comparison with pure alfalfa crop was recorded. The decrease of yield both in comparison with that obtained in 2010 and in comparison with the

Tab. 4. Variation with fertilization dose in the DM yield ( $\left(\cdot \mathrm{ha}^{-1}\right)$

\begin{tabular}{ccccc}
\hline Fertilization & $\begin{array}{c}\text { DM yield } \\
\left(\mathrm{t} \cdot \mathrm{ha}^{-1}\right)\end{array}$ & $\begin{array}{c}\text { Yield } \\
\%\end{array}$ & $\begin{array}{c}\text { Differences } \\
+/-\left(\mathrm{t} \cdot \mathrm{ha}^{-1}\right)\end{array}$ & Significance \\
\hline F1 & 11.89 & 100.0 & 0.00 & Control. \\
\hline F2 & 12.26 & 103.1 & 0.37 & $*$ \\
\hline F3 & 12.58 & 105.9 & 0.70 & $* * *$ \\
\hline
\end{tabular}

Tab. 5. Biological and economic characteristics of species within the mixtures (version after Motcă et al., 1994, Rotar and Carlier 2005 and personal observations)

\begin{tabular}{|c|c|c|c|c|c|c|c|c|c|}
\hline \multirow{2}{*}{$\frac{\text { Specie }}{\text { Dactylis glomerata }}$} & \multirow{2}{*}{$\frac{\text { Size }}{\text { high }}$} & \multirow{2}{*}{$\begin{array}{l}\text { Develop- } \\
\text { ment rate }\end{array}$} & \multirow{2}{*}{$\frac{\text { Vivacity }}{\text { medium }}$} & \multirow{2}{*}{$\begin{array}{c}\begin{array}{c}\text { Regrowth } \\
\text { capacity }\end{array} \\
\text { very good }\end{array}$} & \multirow{2}{*}{$\frac{\text { Usage }}{\text { mixed }}$} & \multicolumn{2}{|c|}{$\begin{array}{l}\text { Competi- } \\
\text { tiveness }\end{array}$} & \multicolumn{2}{|c|}{$\begin{array}{c}\text { Behaviour at } \\
\text { fertilization /irigation }\end{array}$} \\
\hline & & & & & & III & I & very good & good \\
\hline Festuca pratensis & medium & medium & medium & poor & mixed & II & III & very good & very good \\
\hline Lolium perenne & small & rapid & short & very good & grazing & I & II & good & good \\
\hline Lolium multiflorum & high & rapid & short & very good & meadow & I & I & good & very good \\
\hline Lolium $\mathrm{x}$ hybridum & high & rapid & short & very good & meadow & I & I & good & very good \\
\hline $\begin{array}{l}\text { Festulolium braunii } \\
\text { italian type }\end{array}$ & high & rapid & medium & very good & mixed & I & I & very good & very good \\
\hline Phleum pratense & high & medium & medium & good & mixed & III & III & very good & very good \\
\hline Lotus corniculatus & small & medium & medium & very good & mixed & III & III & good & good \\
\hline Trifolium pratense & high & rapid & short & very good & meadow & II & II & good & good \\
\hline Trifolium repens & small & medium & medium & very good & grazing & III & III & good & good \\
\hline T. alexandrinum & high & rapid & short & very good & meadow & I & - & good & good \\
\hline
\end{tabular}


Tab. 6. The influence of mixtures on the DM yields $\left(\mathrm{t} \cdot \mathrm{ha}^{-1}\right)$

\begin{tabular}{ccccc}
\hline Mixture & DM yield $\left(\mathrm{t} \cdot \mathrm{ha}^{-1}\right)$ & Yield & Differences $+/-\left(\mathrm{t} \cdot \mathrm{ha}^{-1}\right)$ & Significance \\
\hline M1 & 10.09 & 100 & 0 & Control. \\
\hline M2 & 12.26 & 121.6 & 2.18 & $* * *$ \\
\hline M3 & 10.44 & 103.5 & 0.35 & - \\
\hline M4 & 11.82 & 117.2 & 1.74 & $* *$ \\
\hline M5 & 13.52 & 134.1 & 3.44 & $*$ \\
\hline M6 & 10.68 & 105.9 & 0.6 & $* * *$ \\
\hline M7 & 15.37 & 152.4 & 5.28 & $* * *$ \\
\hline M8 & 14.42 & 142.9 & 4.33 & $* *$ \\
\hline M9 & 11.57 & 114.7 & 1.49 & LSD (p 0.1\%) 1.82 \\
\hline \multicolumn{2}{r}{ LSD (p 5\%) 0.96} & & LSD (p 1\%) 1.32 &
\end{tabular}

Tab. 7. The combined influence of mixture and fertilization on the DM yield $t \cdot \mathrm{ha}^{-1}$ )

\begin{tabular}{|c|c|c|c|c|}
\hline Mixture/F1 & DM yield $\left(\mathrm{t} \cdot \mathrm{ha}^{-1}\right)$ & Yield \% & Differences $+/-\left(\mathrm{t} \cdot \mathrm{ha}^{-1}\right)$ & Significance \\
\hline M1 & 9.82 & 100.0 & 0.00 & Control. \\
\hline M2 & 11.87 & 120.9 & 2.05 & $* *$ \\
\hline M3 & 9.88 & 100.6 & 0.06 & - \\
\hline M4 & 11.14 & 113.5 & 1.32 & $*$ \\
\hline M5 & 12.99 & 132.3 & 3.17 & $* * *$ \\
\hline M6 & 9.97 & 101.6 & 0.16 & - \\
\hline M7 & 15.49 & 157.8 & 5.67 & $* * *$ \\
\hline M8 & 14.53 & 148.0 & 4.71 & $* * *$ \\
\hline M9 & 11.27 & 114.8 & 1.45 & $*$ \\
\hline Mixture/F2 & DM yield $\left(\mathrm{t} \cdot \mathrm{ha}^{-1}\right)$ & Yield \% & Differences $+/-\left(\mathrm{t} \cdot \mathrm{ha}^{-1}\right)$ & Significance \\
\hline M1 & 10.04 & 100.0 & 0.00 & Control. \\
\hline M2 & 12.35 & 123.0 & 2.31 & $* *$ \\
\hline M3 & 10.48 & 104.3 & 0.43 & - \\
\hline M4 & 11.88 & 118.3 & 1.84 & $* *$ \\
\hline M5 & 13.69 & 136.3 & 3.64 & $* * *$ \\
\hline M6 & 11.15 & 111.0 & 1.11 & - \\
\hline M7 & 15.07 & 150.1 & 5.03 & $* * *$ \\
\hline M8 & 14.12 & 140.6 & 4.08 & $* * *$ \\
\hline M9 & 11.54 & 115.0 & 1.50 & $*$ \\
\hline Mixture/ F3 & DM yield $\left(\mathrm{t} \cdot \mathrm{ha}^{-1}\right)$ & Yield \% & Differences $+/-\left(\mathrm{t} \cdot \mathrm{ha}^{-1}\right)$ & Significance \\
\hline M1 & 10.40 & 100.0 & 0.00 & Control. \\
\hline M2 & 12.57 & 120.9 & 2.17 & $* *$ \\
\hline M3 & 10.96 & 105.4 & 0.56 & - \\
\hline M4 & 12.45 & 119.8 & 2.06 & $* *$ \\
\hline M5 & 13.90 & 133.7 & 3.51 & $* * *$ \\
\hline M6 & 10.93 & 105.1 & 0.53 & - \\
\hline M7 & 15.53 & 149.4 & 5.13 & $* * *$ \\
\hline M8 & 14.60 & 140.4 & 4.20 & $* * *$ \\
\hline M9 & 11.90 & 114.5 & 1.50 & $*$ \\
\hline \multicolumn{5}{|c|}{ LSD (p 5\%) 1.32; LSD (p 1\%) 1.79; LSD (p 0.1\%) 2.42} \\
\hline
\end{tabular}


yield of pure alfalfa crop in 2011 can be attributed to the disappearance of T. alexandrinum specie in the sward. A relation between the disappearance of T. alexandrinum specie after one year and the decrease of DM yield was observed also in M7 mixture. The decrease of yields of all mixtures and pure alfalfa crop in 2011 (Tab. 3) was influenced by weather conditions, especially by the small amount of rainfalls (Tab. 1) recorded both in spring at the starting in vegetation of plants (March-April) and during vegetation period, after each cutting (June, July and August).

Analysing only the influence of mixtures on the average yields of the two experimental years it can be observed that the mixtures recorded higher yields in comparison with the yield of pure alfalfa crop, regardless the number of species they contain. On the first three places they can be mentioned M7, M8 and M5 mixtures (Tab. 6).

The combined influence of mixture and fertilization on the DM yield revealed the same classification of mixtures on the three fertilization levels (M7, M8 and M5), respectively very significant yield increases in comparison with pure alfalfa crop (Tab. 7). The interaction between the two experimental factors shown a good reaction of pure alfalfa crop to the increase of $\mathrm{N}$ applied dose. The species within M4 mixture had also a good reaction at $\mathrm{N} 60 \mathrm{P} 70 \mathrm{~kg} \cdot \mathrm{ha}^{-1}$ fertilization dose. Fertilization determined at M4 mixture a yield increase in comparison with the yield of pure alfalfa crop and more statistical significant than the yield of unfertilized M4 mixture.

Interesting evolutions of harvests at N60P70 $\mathrm{kg} \cdot \mathrm{ha}^{-1}$ fertilization dose can also be observed in M7 and M8 mixtures. Thus, the yield increases obtained indicated a smaller reaction of species within mixtures in comparison with pure alfalfa crop but also in comparison with their unfertilized variants. This evolution show the possibility to renounce at moderate dose fertilization for these mixtures in economic efficiency conditions.

\section{CONCLUSION}

The mixtures which had in their composition species with high and medium competitiveness, but also with a rapid development rate provided distinctly significant and very significant yield increases in the first year of vegetation.
The dissapearance in the second year of vegetation from the sward of M2 (first year - 4 species) and M7 (first year - 7 species) of species with short vivacity such as $T$. alexandrinum determined decreases of yields in comparison with the yields obtained in the first year of vegetation. Moreover the yield of M2 mixture decreased also in comparison with the yield o pure alfalfa crop but not significantly. The M7 mixture with 6 species in composition provided even in the second year of vegetation a very significantly yield increase in comparison with pure alfalfa crop.

The mixtures which had very significant yield increases in comparison with pure alfalfa crop regardless the level of fertilization and year were M7, M8 (new mixtures) and M5 (mixture already on market). The knowledge of reaction of some mixtures of perennial fodder species both at specific ecological conditions of an area and at the utilization of certain fertilization doses permit the choose of the most convenient technological variants.

Acknowledgments. „This work was supported by CNCSIS-UEFISCSU, project number PNII-IDEI 1488/2008".

\section{REFERENCES}

1. Dragomir N. (2005). Pajişti şi plante furajere - tehnologii de cultivare. Editura Eurobit, Timișoara.

2. Motcă Gh., I. Oancea L.-I. Geamănu (1994). Pasture of Romania. Typology and technology, Handbook, Ed. Tehn. Agricolă. București, Romania, 97-150.

3. Rotar I. and L. Carlier (2005). Pastures culture. Ed. Risoprint, Cluj-Napoca. p. 9-27.

4. Schitea Maria, T. Martura, P. Varga, E. Constantinescu, D. Todoran, C. Timirigaziu and Alexandrina Dihoru (2002). New cultivars of aristate ryegrass (Lolium multiflorum Lam.) and hybrid ryegrass (Lolium hybridum Hausskn.) released AT A.R.D.I. Fundulea.Romanian agricultural research. Number 17-18.

5. Schitea, M. and P. Varga (2007). Achievements in fodder plants' breeding at Fundulea. An. I.N.C.D.A. Fundulea 75:203-227.

6. Varga, P., Al. Moisuc, M. Savatti, M. Schitea, C. Olaru, N. Dragomir and M. Savatti jr. (1998). The breeding of fodder plants and the production of seeds. Editura Lumina.

7. Vîntu V., A. Moisuc, Ghe. Motcă and I. Rotar (2004). Fodder plants and pastures culture. Ed. Ion Ionescu de la Brad, Iaşi. p. 17 -57.

8. 8.http://www.dlfis.com/Forage/Species_and_varieties/ Festulolium.aspx 